\title{
FACTORS RELATING TO THE UTILIZATION OF NCD INTEGRATED POST
}

\author{
Hadafiah $^{1} *$, Sunarsih $^{2}$, Erwin Azizi Jayadipraja ${ }^{3}$, Putu Suri Saraswati ${ }^{4}$, Sartini Risky $^{5}$ \\ 1,2,3,4,5 Mandala Waluya College of Health Sciences Kendari, \\ Southeast Sulawesi, Indonesia
}

Corresponding Author: Hadafiah

Email :hadafiah1710@gmail.com

\section{Abstract}

Background: Indonesia has the highest prevalence of Non-Communicable Disease (NCD)in 2013. NCD which is always listed in the top 10 diseases in Southeast Sulawesi is hypertension and diabetes mellitus. NCD Integrated Post is an effort to detect and overcome the early presence of NCD threat factors. However, there has been a decrease in the prevalence of integrated post visits from 2017 to 2018 at the Barangka Public Health Centre. The purpose of this study was to analyze the utilization of NCD Integrated Post in the work area of Barangka Health Centre in Buton Regency.

Methods: This type of research uses a cross-sectional study design. This study was conducted from November to December 2019. The population in this study were all people in the work area of Barangka Health Centre, Buton Regency in 2018 with ages> 15 to 59 years, namely 3,584 people. The number of the samples was 134 respondents. A questionnaire was used as the method of data collection.

Results: The results showed that the chi square of cadre support X2 count $=36,460>\mathrm{X} 2$ table value $=3,841$ and health status is $\mathrm{X} 2$ count $=32,308>$ table $\mathrm{X} 2$ value $=3,841$. Therefore, all variables are influencing the utilization of NCD Integrated Post.

Conclusion: Health status and cadre influenced significantly the community in utilizing NCD Integrated Post at the Barangka Health Centre in Buton Regency.

Keywords: NCD; Integrated Post; Health Status; Cadre Support 


\section{INTRODUCTION}

In today's world changes in the incidence of disease take shape marked by epidemiological transitions. Noncommunicable diseases undergo a transitional form change, which was originally controlled by infectious diseases. As the frequency of non-communicable diseases (NCD) develops (1). World Health Organization data which explains that as many as fifty-seven million (63\%) mortality rates and thirty-six million (43\%) morbidity rates are referred to as Non-communicable Diseases (2).

In Indonesia in 2013 the highest prevalence of $\mathrm{NCD}(3)$. NCD which is always listed in the top 10 diseases in Southeast Sulawesi is hypertension and diabetes mellitus. For 2015, hypertension was ranked second with a total of 19,743 cases, while diabetes mellitus was ranked fifth with a total of 3,206 cases(4).

By involving empowerment and developing the role of the community is a strategic way to prevent various risk factors early(5). Services that involve the role of the community with promotiveand preventive efforts are NCD Integrated Post activities to detect and address early the existence of NCD threat factors systematically(6). Based on data from the Buton District Health Office in 2018 the distribution of NCD Integrated Post for the Buton District amounted to 41 consisting of 14 Primary Health Centre (7). Barangka Community Health Center as the most public health center and integrated post with the number, in Buton Regency, is 11 integrated posts. Based on data obtained from the Barangka Primary health Center that in 2017 there were 255 visitors to integrated posts with a prevalence of $44.2 \%$. In 2018, 248 people were visiting integrated post with a prevalence of $43.5 \%$. This shows that the prevalence of visits decreased from 2017 to 2018(8).

The behavior of individuals visiting health services is determined by three aspects. i.e. priority aspects (i.e. knowledge, attitudes, beliefs, values, individual characteristics), enabling factors (i.e. readiness, government law in preparing health-related facilities) whereas (skills and distance to health service) are reinforcing factors(9). Preliminary Survey conducted at the location of researchers obtained information that the average level of education is still lacking community knowledge about the integrated post is still low, some people will get sick and there will be no counseling from health workers.

\section{METHOD}

This type of research uses a crosssectional study design(10). This study was conducted from November to December 2019. The population in this study were all people in the work area of Barangka Health Centre, Buton Regency in 2018 with ages> 15 to 59 years, namely 3,584 people.From the calculation of the samples, the obtained sample at a minimum of 134 samples(11). A questionnaire was used as the method of data collection(12).

\section{RESULT}

The results of statistical tests obtained the value of chi-squareX2 count $=36,460>$ table $\mathrm{X} 2$ value $=3,841$. This shows that $\mathrm{H} 0$ was rejected and $\mathrm{Ha}$ was accepted, meaning that there was a relationship between cadre support and the use of NCDIntegrated post in Barangka Health Centre, Buton Regency. The results of statistical tests obtained the value of chisquareX2 count $=32,308>$ table $\mathrm{X} 2$ value $=$ 3,841 . This shows that $\mathrm{H} 0$ was rejected and Ha was accepted, meaning that there was a relationship between health status and the utilization of NCD Integrated Post in Barangka Health Centre, Buton Regency.

Distribution of cadre support relationships with the use of NCD Integrated Post in Barangka Health Centre, Buton Regency are as follows: 
Hadafiah, Sunarsih, Jayadipraja, E. A., Saraswati, P. S., \& Risky, S. DOI: 10.36566/ijhsrd/Vol2.Iss1/15

https://ijhsrd.com/index.php/ijhsrd

e- ISSN: 2715-4718

Table 1

Distribution of cadre support relations with the Utilization of NCD Integrated post in the Barangka Health Centre of Buton Regency

\begin{tabular}{|c|c|c|c|c|c|c|c|}
\hline \multirow{3}{*}{ Cadre support } & \multicolumn{4}{|c|}{$\begin{array}{l}\text { Utilization of NCD } \\
\text { Integrated Post }\end{array}$} & \multicolumn{2}{|c|}{ Total } & \multirow{3}{*}{ Statistic test } \\
\hline & \multicolumn{2}{|c|}{ Enough } & \multicolumn{2}{|c|}{ Less } & & & \\
\hline & $\mathbf{n}$ & $\%$ & $\mathrm{n}$ & $\%$ & $\mathbf{n}$ & $\%$ & \\
\hline Enough & 45 & 70.3 & 19 & 29.7 & 64 & 100 & $X 2$ count $=36,460$ \\
\hline Less & 13 & 18.6 & 57 & 81.4 & 70 & 100 & $\rho$ value $=0,000$ \\
\hline Total & 58 & 43.3 & 76 & 56.7 & 134 & 100 & $\begin{array}{l}\mathrm{X} 2 \text { table }=3,841 \\
\alpha=0.05\end{array}$ \\
\hline
\end{tabular}

The distribution of the relationship between health status and the utilization of NCD

Integrated Post in Barangka Public Health Centre, Buton Regency, are as follows:

Table 2

Distribution of the relationship of health status with the Utilization of NCD Integrated Post in Barangka Health Centre, Buton Regency

\begin{tabular}{|c|c|c|c|c|c|c|c|}
\hline \multirow{3}{*}{ Health status } & \multicolumn{4}{|c|}{$\begin{array}{l}\text { Utilization of NCD } \\
\text { Integrated Post }\end{array}$} & \multicolumn{2}{|c|}{ Total } & \multirow{3}{*}{ Statistic test } \\
\hline & \multicolumn{2}{|c|}{ Enough } & \multicolumn{2}{|c|}{ Less } & & & \\
\hline & n & $\%$ & $\mathbf{n}$ & $\%$ & $\mathbf{n}$ & $\%$ & \\
\hline NCD sufferers & 51 & 63.0 & 30 & 37.0 & 81 & 100 & $\mathrm{X} 2$ count $=32,308$ \\
\hline NCD sufferers & 7 & 13.2 & 46 & 86.8 & 53 & 100 & $\rho$ value $=0,000$ \\
\hline Total & 58 & 43.3 & 76 & 56.7 & 134 & 100 & $\begin{array}{l}\mathrm{X} 2 \text { table }=3,841 \\
\alpha=0.05\end{array}$ \\
\hline
\end{tabular}

\section{DISCUSSION}

Relationship between cadre support and utilization of NCD Integrated Post in Barangka Health Centre, Buton Regency

The role of cadres is one of the supporting factors that play a role in health behavior because it is a behavioral accompanying factor that gives effect and contributes to the permanent or disappearance of behavior (13). The implementation of NCD Integrated post is carried out by existing health cadres (14)or several people from each group/organization/institution/workplace who are willing to hold NCD Integrated post with the criteria of having a minimum of high school education, willing and able to carry out activities related to NCD integrated post(15).

The results of statistical tests obtained the value of chi-square X2 count $=36.460>$ table $\mathrm{X} 2$ value $=3,841$. This shows that $\mathrm{HO}$ was rejected and Ha was accepted, meaning that there was a relationship between cadre support and the utilization of NCD Integrated Post in the Barangka Health Centre of Buton Regency. The relationship shows that cadre support is one of the factors that influence the community in utilizing NCD Integrated Post. Thus the better the support of cadres in providing counseling about the NCD Integrated Post-program, the more people who are interested in utilizing NCD Integrated Post. 
According to researchers the lack of cadre initiative in inviting public health in an Integrated post also caused a lack of community motivation to visit. Therefore, they need to monitoring and evaluation of the implementation of the integrated health post so that the quality of service becomes better. The results of this study are in line with Ratna Sari's research (2018) that the Chi-Square test results were obtained p-value of 0,000 which means there is a relationship between cadre support and the utilization of NCD Integrated Post in the work area of the Primary Health Centre in Setiabudi District, South Jakarta City(16)..

\section{Relationship between health status and utilizationNCD Integrated Post in Barangka Health Centre, Buton Regency}

Every person who feels themselves healthy even though they are not medically sure they are healthy is a proof to show a healthy perception(17). On the contrary, people feel sick and lying weak, they were able to carry out their activities at that time(18). New communities take advantage when the community can no longer work activity and feel sick. if taking the recommended behavior then the benefits to be enjoyed are related to feeling (perceived) and useful (benefit)(19).

The results showed that of 81 respondents have health status as NCD sufferers there are still 30 respondents $(37.0 \%)$ using Integrated post less. This is caused by respondents choosing their alternative to seek treatment or seek a place of treatment where they have heard or felt that their other theme is healed and healthier than visiting the integrated post.

There is a relationship between health status and the utilization of NCD Integrated Post in Barangka Primary Health Centre, Buton Regency. The relationship shows that health status is one of the factors that influence the community in utilizing NCD Integrated Post. Thus, the more people suffering from NCD who are interested in utilizing NCD Integrated health Post. The results of this study comparable Sasongko's research (2019) that based on the results of cross-tabulation between the health status of respondents with the use of NCD Integrated Post, p-value 0,000 was obtained because pvalue $<0.05$ then $\mathrm{H} 0$ was rejected, which means there is a significant relationship between the health status of elderly women with the use of NCD Integrated Post in the working area of the Cilongok Health Centre(20).

\section{CONCLUSIONS}

Health statusis one of the factors that influence the community in utilizing NCD Integrated Post. Other than that, cadre support is also a factor influencing the utilization of NCD Integrated Post in Barangka Public Health Centre, Buton Regency.Because the utilization of NCD Integrated Post is still very low, so efforts are needed to increase utilization through promotion and counseling about the benefits of Integrated post, increase socialization regarding NCD Integrated Post schedules, increase cadre capabilities with training and carry out monitoring and evaluation.

\section{REFERENCES}

1. WHO. Global Status report on noncommunicable Disease 2014. Airlangga UniversityPress. 2010.

2. WHO. Global status report on noncommunicable diseases 2014: World Health Organization; 2015.

3. Ministry of Health. Health Profile 2015. Indonesia Health Profile Year2015;2015:125. (Indonesia)

4. Health Office of Southeast Sulawesi Province. Health Profile of Southeast Sulawesi Province. Southeast Sulawesi: Health Office of Southeast Sulawesi Province; 2015. (Indonesia)

5. Jayadipraja EA, Prasetya F, Azlimin A, Mando WOSY. Family Clean And Healthy Living Behavior And Its 
Hadafiah, Sunarsih, Jayadipraja, E. A., Saraswati, P. S., \& Risky, S. DOI: 10.36566/ijhsrd/Vol2.Iss1/15

https://ijhsrd.com/index.php/ijhsrd

e- ISSN: 2715-4718

Determinant Factors In The Village Of Labunia, Regency Of Muna, Southeast Sulawesi Province Of Indonesia. Public Health of Indonesia. 2018;4(1):39-45.

6. Saraswati PS. Correlation Of Supervision, Opportunities For Advancement And Job Safety With Satisfaction Of Puskesmas Employees In North Konawe District. Indonesian Journal Of Health Sciences Research And Development (Ijhsrd). 2019;1(1):921.

7. Health Office of Buton. Health Profile of Buton. Buton: Buton Health Office; 2018.(Indonesia)

8. PHC of Barangka. Health Profile of PHC Barangka. Publika. 1918;5(5). (Indonesia)

9. Bennet F, J. Community Diagnosis and Health Program. Journal of Pitutur Psychology. 1987; vol. 1, no. 1, hlm. 5767.(Indonesia)

10. Mackey A, Gass SM. Second language research: Methodology and design: Routledge; 2015.

11. Misra RP. Research Methodology: a Hand Book: Concept Publishing Company; 1989.

12. Ebert JF, Huibers L, Christensen B, Christensen MB. Or web-based questionnaire invitations as a method for data collection: cross-sectional comparative study of differences in response rate, completeness of data, and financial cost. Journal of medical Internet research. 2018;20(1):e24.

13. Poland BD, Green LW, Rootman I. Settings for health promotion: linking theory and practice: Sage Publications; 1999.

14. Somanathan A, Finkel E, Arur A. Strengthening Integrated Care in Central and Eastern Europe. World Bank; 2019.

15. Ministry of Health. Basic health research; RISKESDAS. Jakarta:
Balitbang RI Ministry of Health. 2013;2013:110-9. (Indonesia)

16. Sari R, Putri SE, Herdi H, Hamuddin B. Bridging critical discourse analysis in media discourse studies. Indonesian EFL Journal. 2018;4(2):80-9.

17. Wallston KA, Wallston BS, Smith S, Dobbins CJ. Perceived control and health. Current Psychology. 1987;6(1):5-25.

18. Deutsch A. The mentally ill in AmericaA History of their care and treatment from colonial times: Read Books Ltd; 2014.

19. Abdullah NRA, Jason WLC, Nasruddin AB. Pachydermoperiostosis: a rare mimicker of acromegaly. Endocrinology, Diabetes \& Metabolism Case Reports. 2017;2017(1).

20. Sasongko HP, Nanda FD, Fitriyati F, editors. Community Knowledge Level About The Utilization Of Integrated Coaching Pos Of Noncomunicbale Disease (Posbindu Ptm) With The Prevalence Of Noncommunicable Disease At Age 15-59 In Working Area Of Wonosobo Health Center In Srono Banyuwangi 2018. Procceeding the 4th International Nursing Conference; 2019. 